
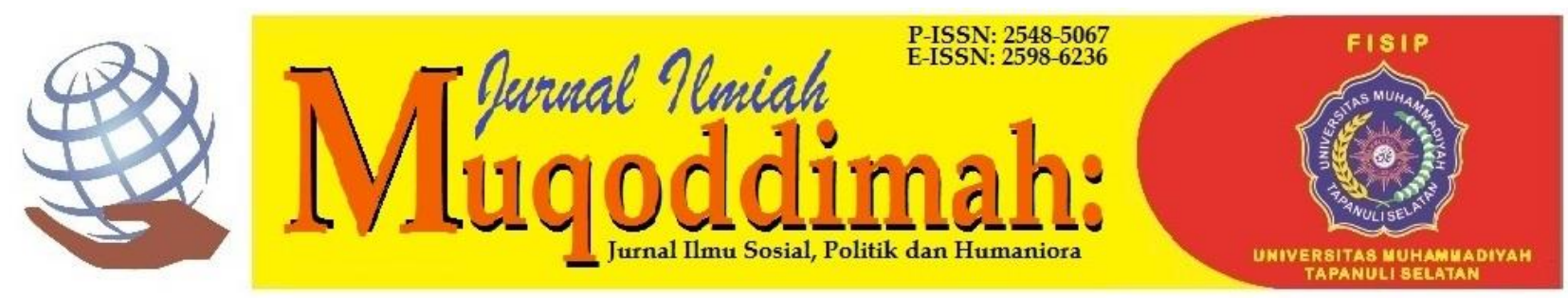

\title{
Kontribusi Relawan Aku Belajar (Studi Pelaksanaan Budaya Literasi Pada Anak Pemulung)
}

\author{
Iwan Ramadhan'1) Imran²) \\ Pendidikan Sosiologi Fakultas Keguruan dan IImu Pendidikan Universitas Tanjungpura \\ Jl. Prof. Dr. H. Hadari Nawawi, Kota Pontianak, Indonesia \\ iwan.ramadhan@untan.ac.id'1) \\ imran@fkip.untan.ac.id²)
}

\begin{abstract}
Abstrak
Pemerintah mencanangkan budaya literasi sebagai salah satu pilihan untuk meningkatkan taraf pendidikan yang berkelanjutan; Dalam perkembangannya budaya literasi masih sangat minim bahkan memprihatinkan, banyaknya open literacy yang masih dominan merupakan bukti masih rendahnya literasi di Indonesia pada umumnya, termasuk untuk anak-anak. Anak-anak pemulung yang ternyata masih membutuhkan perhatian khusus, Relawan Aku Belajar merupakan salah satu lembaga swadaya masyarakat yang didirikan oleh para pemuda yang tergerak untuk melakukan kegiatan kepedulian sosial khususnya di bidang pendidikan; Dalam penelitian ini akan diuraikan proses pelaksanaan kegiatan pembelajaran berbasis budaya literasi. Anak-anak pemulung di sekitar TPA di Desa Batulayang menggunakan pendekatan kualitatif, deskripsi yang mendalam melalui observasi dan wawancara. Hasil yang diperoleh dalam penelitian ini adalah penerapan budaya literasi terbagi menjadi tiga bagian utama, yaitu proses pembelajaran budaya literasi pembukaan, proses kegiatan inti, dan proses penutupan kegiatan penerapan budaya literasi pada anak pemulung yang membiasakan diri membaca dan menulis melalui kontribusi Relawan Aku Belajar.
\end{abstract}

Kata kunci: Anak Pemulung, Budaya Literasi, Relawan Aku Belajar

\begin{abstract}
The government has proclaimed the culture of literacy as an option to improve the level of education that is sustainable; in its development, the culture of literacy is still very minimal and even alarming, the number of open literacy which is still dominant is evidence that literacy is still low in Indonesia in general, including for children. Scavenger children who, in fact, still need special attention, the Aku Belajar Volunteer is one of the non-governmental organizations founded by young people who are moved to carry out social care activities, especially in the field of education; in this study, the process of implementing learning activities based on a culture of literacy will be described. Scavenger children around the landfill in Batulayang Village use a qualitative approach, in-depth descriptions through observation and interviews. The results obtained in this study are the implementation of literacy culture is divided into three main parts, which are the process of opening literacy culture learning, the process of core activities, and the closing process of activities in implementing literacy culture in scavenger children who are getting used to reading and writing through the contribution of the Aku Belajar Volunteers.
\end{abstract}

Key words: Scavenger Children, Literacy Culture, Aku Belajar Volunteers 


\section{PENDAHULUAN}

Setiap manusia mempunyai hak atas pendidikan, siapapun, dimanapun dan kapanmu setiap individu memiliki hak yang sama dalam mendapatkan pendidikan, terlebih pendidikan merupakan sesuatu hal yang sangat penting, oleh karenanya perlu adanya kesiapsiagaan terkait ujung dari akhir suatu kehidupan yaitu dalam proses adanya pendidikan akan menghasilkan kegiatan-kegiatan yang berkaitan dengan sosial, ekonomi, budaya, kesehatan dan sebagainya. Kemudian sebagai insan yang memiliki jiwa sosial tentunya memberikan pengaruh bagi kehidupan kedepannya. Namun terkadang kendala pada problematika kemiskinan yang menjadi salah satu faktor masalah yang hingga saat sekarang ini dan terus berlanjut, (Jefriyanto, 2019). Fenomena anak putus sekolah masih menjadi wacana yang sampai sekarang masih sangat besar, hal ditandai juga dengan adanya masyarakat yang masih buta huruf yang bisa kita sebut buta aksara, yang masih saja diusahakan oleh pemerintah untuk diberikan solusi, (Kuntoro, 2016).

Pendidikan nonformal juga merupakan salah satu pilihan untuk melengkapi dari pendidikan formal, (Ali Anwar, Noer Hidayah, 2017), begitu halnya dengan tujuan dari dibentuknya program Aku Belajar. Peranannya paling sering diekspose di berbagai literatur guna mengatasi permasalahan yang terjadi dimasyarakat pada khususnya anak-anak pemulung, dengan demikian tujuan utamanya adalah sebagai upaya mengurangi terjadinya anak putus sekolah dan melek huruf, (Imsiyah, 2016).

Pemulung merupakan salah satu golongan sosial yang memiliki kegiatan mengumpulkan barang-barang bekas yang dapat di daur ulang ataupun masih dapat digunakan, (Huzaemah, 2020). Penyebab anak ditelantarkan bukan hanya karena persoalan kemiskinan, akan tetapi pada kenyataan dikehidupan, "faktor kemiskinan tersebut merupakan kerentenan bagi ekonomi keluarga sehingga dapat menyebabkan mereka terkendala dalam memenuhi hak anaknya" (Suyanto, 2013). Melihat fakta dikehidupan nyata, hak anak pemulung termasuk dalam kategori anak yang terlantar. Karena itu, hak yang seharusnya mereka miliki tidak dapat terpenuhi seperti pada hak dalam kebutuhan makan, pakaian, pendidikan serta kesehatan. Hal ini kemudian memicu munculnya lembaga sosial masyarakat atau organisasi sosial yang peduli terhadap pemenuhan kebutuhan anak, terutama kebutuhan dalam hal pendidikan. Terkadang anak-anak pemulung juga sambil bekerja membantu orang tuanya, tentunya hal tersebut memberikan dampak negatif bagi anak, semisal, kenyamanan umur anak yang notabanenya waktu bermain, serta gangguan kesehatan, (Lelya Hilda, 2017).

Adapun solusi yang menjadi harapan utama dalam pengembangan kemajuan pendidikan yang bergerak salah satunya adalah adanya relawan yang bekerja sukarela untuk memberikan pendidikan kepada anak-anak yang membutuhkan salah satunya adalah Program relawan Aku Belajar yang digagas oleh pemuda-pemudi yang berlatar belakang pendidikan mayoritas adalah sedang menjadi mahasiswa, mahasiswa-mahasiswa tergerak hatinya untuk peduli antar sesama dengan mengedepankan bahwa pendidikan merupakan poin penting bagi kehidupan bangsa, pendidikan non formal menjadi salah satu pilihan yang memiliki peranan sangat penting bagi masyarakat yang takkan pernah habis permasalahannya, (Pratiwi \& Wibhawa, 2015).

Dilansir dari tribun pontianak pada jum'at, 9 November 2018 Disdikbud Kalbar menyebutkan bahwa angka buta aksara mencapai 1,76 \% dari 4 juta penduduk dan Indeks aktivitas literasi membaca di 34 provinsi, Kalimantan Barat berada di posisi 3 terendah dari 34 provinsi dengan persentase $28,63 \%$. Dari data tersebut membuktikan bahwa kemampuan literasi anak di Kalbar terbilang rendah ((Sholihin et al., 2019). Literasi merupakan suatu kemampuan yang dimiliki seseorang dalam mengelola informasi, membaca, menulis, menggunakan media serta akitivas untuk mendapatkan pengetahuan lainnya untuk dijadikan kemampuan dalam perihal bermasyarakat (Agusta, 2020). Menurut (Wang \& Anderson, 2010) "Membaca buku bersama dan meningkatkan volume membaca dapat meningkatkan penguasaan kosa kata. Bahwasanya, tujuan dari membaca untuk dapat mengembangkan pengetahuan dan potensi yang dimiliki seseorang untuk bisa berpartisipasi di lingkungan masyarakat".

Pada pelaksanaan pendidikan, yang menjadi faktor penghambat dalam pendidikan yang utamanya adalah budaya literasi yang masih sangat minim ditambah lagi fasilitas 
sekolah yang belum tercukupi, seperti koleksi bacaan yang masih kurang, metode yang diajarkan oleh guru disekolah masih bersifat konvensional, dan sadar akan pentingnya membawa menjadi awal dari permasalahan yang ada saat sekarang, (Imran et al., 2017). Selain itu menulis juga tidak kalah pentingnya, karena membaca dan menulis merupakan produk penting dari peradaban umat manusia. Secara harfiah membaca dan menulis merupakan proses yang melekat pada suatu objek yaitu tulisan. Banyak yang berkata perihal membaca merupakan proses untuk menambah wawasan sehingga pengetahuan yang didapat akan semakin meningkat maka dengan menulis juga merupakan suatu cara untuk menyajikan kembali pengetahuan yang diperoleh kepada masyarakat luas (Rahmadhani \& Raksun, 2021).

Beberapa penelitian terdahulu mengungkapkan bahwa peran dari relawan dibidang pendidikan melalui budaya literasi mampu meningkatkan minat belajar, hasil dan prestasi belajar anak pemulung, (Ulmi \& Ramadhan, 2021). Selanjutnya Partisipasi relawan sangat berperan penting dalam kegiatan meningkatkan minat baca bagi masyarakat, (Rahayu \& Nurizzati, 2018). Disisi lain penelitian ini bertujuan untuk mendeskripsikan pelaksanaan budaya literasi pada anak pemulung melalui kontribusi Relawan Aku Belajar. Pelaksanaan kegiatan membuka dilakukan dengan membaca lima menit pada buku pelajaran, kegiatan inti yaitu dengan membaca nyaring dan menulis berupa menguatan, serta penutup berupa evaluasi dengan membuat karya tulis, (Rusdiana, Sulistyarini, 2021).

Melihat permasalahan mengenai pendidikan anak pemulung maka dari itu diperlukannya pendidikan yang mengarah ke keaksaraan sebab terdapat seseorang yang tidak mampu dalam literasi yang memiliki dampak terhadap ketidakmampuan seseorang untuk mendapatkan sebuah pengetahuan yang ada. Maka solusi dari permasalahan ini adalah membantu pengembangan pendidikan melalui program pendidikan, seperti program Aku Belajar yang ada di TPAS Batu Layang. Oleh sebab itu peneliti tertarik membahas tentang bagiamana kontribusi Relawan Aku Belajar dalam melaksanakan budaya literasi membaca untuk pendidikan anak pemulung di TPAS Batu Layang.

\section{METODE}

Metode penelitian yang digunakan ialah metode kualitatif deskriptif, guna memberikan pemahaman terhadap fenomena yang terjadi dilapangan dengan berbagai aspek yang berupa persepsi, perilaku, kegiatan ataupun tindakan yang bersifat nyata dengan sesuai dengan apa yang benar-benar terjadi dilapangan serta menggunakan bahasa yang logis (Ismali Nurdin, 2019). Dalam penelitian ini peneliti menggambarkan faktafakta nyata mengenai kotribusi dari Relawan Aku Belajar dalam mendidik melalui budya literasi membaca untuk pendidikan anak pemulung di sekitaran TPAS Batu Layang, Kecamatan Siantan. Informan yang di observasi dan diwawancarai sebagai sumber data primer adalah Relawan Aku Belajar. Sedangakan sumber data sekunder pada penelitian ini didapat melalui dokumentasi. Data yang diambil yaitu data yang bersangkutan dengan kegiatan ekonomi dan sosial masyarakat sekitar serta jurnal dan buku referensi yang dapat mendukung guna menganalisis hasil dari penelitian tersebut, (Nawawi, 2015)

Adapun alat-alat yang digunakan dalam memudahkan peneliti memperoleh data dan informasi sebagai berikut: panduan observasi, pedoman wawancara, alat dokumentasi. Dalam penelitian ini, perpanjangan pengamatan dan triangulasi dipilih untuk menguji keabsahan suatu data penelitian, (Sugiyono, 2015).

\section{HASIL DAN PEMBAHASAN \\ Anak Pemulung dan Relawan Aku Belajar di TPAS Batu Layang}

Dalam organisasi Aku Belajar mempunyai relawan yang akan menjalankan program pengurus. Para relawan ini berperan layaknya seorang guru bagi anak-anak pemulung di TPAS Batu Layang. Berawal dari gerkan 1Book100Smiles berupa pengumpulan donasi buku di Sekolah Dasar Islam Miftahulsolihin pada tahun 2011 mendapat respon positif dari masyarakat, namun karena banyak anak-anak masih belum bisa membaca yang pada akhirnya menimbulkan ide untuk membentuk sebuah program untuk memotivasi anak-anak untuk belajar, sehingga terbentuknya program Aku Belajar. Sebenarnya anak-anak 
pemulung ini sudah bersekolah formal seperti biasanya, namun dengan kondisi yang hidup pas-pasan mereka lebih mementingkan memulung sampah bekas dengan tujuan untuk membantu orang tua masing-masing dan akhirnya tidak fokus pada sekolah formal tersebut, senada dengan pendapat (Sudiro, 2012), yang mengatakan bahwa anak-anak ikut menjadi pemulung dengan tujuan untuk membantu orang tua, dan mendapatkan uang tambahan, dan memanfaatkan waktu senggang.

Komunitas juga disebut perkumpulan suatu kelompok yang mempunyai tujuan tertentu, memiliki kepercayaan dan rasa saling menghargai, (Hardiyanti Isnin, 2018), salah satunya adalah relawan yang mulai banyak digerakkan oleh pemuda atau mahasiswa yang memiliki kepedulian yang tinggi. Relawan dapat dikatakan sebagai seseorang yang dengan ikhlas secara sukarela untuk melalukan sesuatu hal bersifat baik untuk kepentingan tertentu, (Maria Ulfa, 2019). Pengembangan yang dapat mengurangi kemiskinan, kebodohan, ketidakberdayaan dan keterbelakangan melalui pendidikan salah satunya membentuk sebuah program, yang di gerakkan atas kesadaran para mahasiswa di Kalbar yaitu NPO Aku Belajar. Aku Belajar adalah sebuah Non-Provit organisation (NPO) atau bisa dikatakan sebagai lembaga swadaya bagi masyarakat non-profit khususnya pada bidang pemberdayaan pendidikan. Dalam hal ini Aku Belajar ( $A B)$ dapat dikatakan sebagai sebuah organisasi yang bergerak dalam bidang pemberdayaan pendidikan terutama bagi anakanak. Organisasi Aku Belajar (AB) berdiri di Pontianak pada tanggal 17 Januari 2013, hingga kini sekitar 40-50 orang anak pemulung yang telah dibina oleh organisasi Aku Belajar di Tempat Pembuangan Akhir Sampah (TPAS) Batu Layang dengan jumlah pengurus 25 orang dan sudah ada 8 angkatan relawan. Dalam organisasi Aku Belajar mempunyai relawan yang akan menjalankan program pengurus, dimana relawan ini sudah ada dari angkatan 1 sampai 8 . Angkatan 1 sampai 5 sudah melaksanakan kegiatan di daerah lain yaitu di Kubu Raya dan telah selesai, kemudian untuk angkatan 6 sampai 8 khusus melaksanakan kegiatan di TPAS Batu Layang.

Adanya keinginan untuk memajukan dan kepedulian terhadap pentingnya pendidikan, tentunya membuat relawan yang secara sukarela untuk tergerak memberikan perhatian lebih kepada anak-anak untuk menambah wawasan dan minat baca, (Rahayu \& Nurizzati, 2018), salah satu adalah Organisasi Relawan Aku Belajar, Program Aku Belajar adalah sebuah lembaga non-profit yang telah dilegalkan secara hukum dalam bentuk sebuah yayasan yang mana berisi program kesukarelaan atau volunteer dan memfasilitasi para anak muda dalam melatih kepemimpinan, mengasah dalam kepedulian, inisiatif dan mendedikasikan diri kepada komunitas yang dipilih serta harus turut berperan aktif dalam menghimpun potensi anak muda yang ada di Kalimantan Barat. Diketahui bahwa relawan: Mengarahkan anak untuk mencapai tujuan pembelajaran dan sambil memberi motivasi, membantu anak memilih dan menemukan sumber atau bahan belajar, membantu mengatasi kesulitan belajar, memcahkan masalah yang dihadapi anak yang menyebabkan kesulitan belajar, menyediakan fasilitas (media, metode serta peralatan pembelajaran), dan menciptakan suasana yang menyenangkan dengan menjadikan anak-anak mitra belajar, (Ulmi \& Ramadhan, 2021).

Anak pemulung yang ikut dalam program ini berstatus pelajar PAUD, SD, dan SMP. Dimana anak-anak tersebut setelah pulang sekolah membantu orang tuanya bekerja, ada juga yang mengisi waktu dengan bermain bersama teman-teman sebaya. Anak-anak pemulung juga kebanyak berstatus sebagai pelajar di sekolahnya masing-masing, mereka melakukan aktivitas memulung disaat pulang sekolah dan waktu lainnya, (Fitri, 2017). Mengapa hal ini bisa terjadi, karena orang tua dari pemulung cenderung otoritas yang memiliki aturan kaku dalam membesarkan anaknya, inilah yang menyebabkan anak-anak yang orang tua nya pemulung ikut juga dalam kegiatan memulung padahal hal ini tentu 
berpengaruh terhadap perkembangan anak-anak tersebut, senada dengan (Inayati Ma'rifah, Cut Dhien Nourwahida, 2018), Dan di ketahui bahwa anak-anak di TPAS terdapat masih banyak yang belum bisa untuk membaca dan menulis, sedangkan yang sudah pandai membaca dan menulis jarang membaca buku dan belajar. Hambatan yang sering terjadi pada sekolah ada adalah kurangnya sarana dan prasarana, serta proses pembiasaan yang minim dilakukan di sekolah formal, sehingga menghambat minat dan pekembangan anak untuk belajar terutama membaca, (Rohim \& Rahmawati, 2020). Minat baca anak-anak disana juga rendah yang merupakan akibat dari anak-anak tersebut iku memulung di TPAS Batu Layang, oleh sebab itu perlu adanya suatu gebrakan yang membawa pada perubahan bagi anak-anak pemulung, karena semakin tingginya minat membaca bagi seseorang yang masih dalam tahap perkembangan sangat berpengaruh pada perilaku, mental serta wawasan bagi yang membaca khususnya anak-anak, (Permatasari, 2015).

Berdasarkan hasil wawancara dengan pengurus aku belajar didapatkan informasi bahwa dalam program aku belajar ini terdapat perpustakaan belajar yang bertujuan untuk meningkatkan literasi anak pemulung, dimana dalam kegiatan ini berupa pengumpulan buku bekas layak baca dan layak pakai bagi anak-anak oleh para donatur. Perpusatakaan Aku Belajar didirikan, agar anak-anak yang bisa membaca dapat membaca dan menemukan sumber belajar mereka, sedangkan yang belum bisa membaca akan dibimbing oleh relawan untuk mengenal huruf dan menulis huruf-huruf tersebut, sehingga diharapkan dapat meningkatkan literasi anak-anak pemulung di TPAS Batu Layang, guna meningkatkan minat baca pada anak, perlu adanya fasilitas untuk mencapai hal tersebut salah satu diantaranya adalah perpustakaan, (Muslimin, 2018).

\section{Pelaksanaan Pembelajaran Budaya Literasi Program Aku Belajar pada Anak Pemulung di TPAS Batu Layang}

Pada tahap pelaksanaan pembelajaran berbasis literasi ini dinternalisasikan dalam kegiatan pembelajaran setiap mata pelajaran yang bertujuan dalam mengembangkan kemampuan siswa untuk bisa memamahami bacaan dan juga mengkaitkan dengan pengalaman pribadi maka akan terbentuk pribadi anak dalam pembelajaran sepanjang hayat, (Hendra Kurniawan, 2018). Dalam proses belajar mengajar berbasis literasi yang dilaksanakan oleh relawan kepada anak pemulung dilakukan kegiatan literasi sesuai dengan tahapan yaitu membaca buku di dalam hati selama lima menit sebelum kegiatan pembelajaran dimulai, membaca nyaring dan kegiatan menulis yang dilakukan untuk penguatan karakter dari anak tersebut dan kegiatan menulis sebagai penilaian dan memanfaatkan lingkungan sosial dan buku sebagai bahan untuk memperkaya ilmu pengetahuan, sejalan dengan (Handayani, 2020), dengan adanya budaya literasi bertujuan untuk meningkatkan karakter dari anak-anak yang lebih disiplin, senang memanfaatkan waktu dengan membaca.

\section{Kontribusi Relawan Aku Belajar Literasi saat Pelaksanaan Pembukaan}

Berdasarkan rencana pembelajaran yang disusun oleh relawan Aku Belajar kegiatan pembuka mencakup salam pembuka, berdoa, mengecek kehadiran, apersepsi, kegiatan membaca, menyampaikan tujuan pembelajaran, dan menyampaikan garis besar cakupan materi, yang mana haruslah terdapat pengembangan budaya literasi dengan menyiapkan perumusan program, strategi, sarana dan prasarana, pengelolaan, dan yang terpenting adanya tujuan dari program tersebut guna melihat hasil kinerja yang dikerjakan kedepan, (Saadati \& Sadli, 2019). Hal ini sejalan dengan pendapat (Sumprihatiningrum, 2017) dalam membuka pelajaran guru perlu melakukan, persiapan psikis dan fisik pada anak, memberikan pertanyaan dengan mengkaitkan pembelajaran sebelumnya, menyampaikan dan menjelaskan tujuan pembelajaran, menyampaikan materi-materi yang sesuai dengan silabus. 
Kemampuan anak dalam dilihat dari cara berkomunikasi, bercerita dan berimajinasi, menggunakan bahasa yang enak diucapkan serta dapat memahami bacaan yang diberikan pada dirinya, (Aryani \& Rais, 2018). Dalam pelaksanaan kegiatan pembuka berbasis literasi relawan meminta anak pemulung untuk membaca buku sebelum masuk ke kegiatan inti, namun hal ini tidak selalu dilakukan, dari tiga kali observasi dua pertemuan terdapat kegiatan membaca dan satu pertemuan tidak ada kegiatan membaca, senada dengan hasil wawancara bersama empat anak pemulung pada saat kegiatan pembuka tidak selalu terdapat kegiatan membaca. Persiapan dalam kegiatan menulis dilakukan diawal pembelajaran, relawan meminta anak-anak menyiapkan alat tulis dan mencatat bagianbagian penting mengenai materi. Namun, hal ini di sesuaikan kembali dengan tingkat pengalaman anak-anak binaan, jika anak-anak binaan yang sudah dapat mengenal huruf maka akan langsung masuk ke materi pembelajaran, namun jika tidak mengenal huruf maka anak pemulung akan di bimbing terlebih dahulu untuk mengenal huruf agar memudahkan proses belajar. Pada umumnya pembimbingan dilakukan dengan cara gaya komunikasi dua arah, sehingga menghasilkan kedekatan antara relawan dengan anak dan respon positif dari anak tersebut, (Putri et al., 2019).

Kegiatan membaca dilakukan agar anak pemulung yang dibina terbiasa membaca dan membangun kemampuan literasi membacanya, dari observasi yang dilakukan dua dari tiga kali observasi peneliti melihat relawan mengintruksikan anak pemulung untuk membaca materi di buku dan bahan ajar yang sudah disediakan pada saat kegiatan pembuka yang disesuaikan dengan materi yang akan mereka pelajari, tujuannya untuk meningkatkan minat baca anak pemulung yang dibina. Ini sejalan dengan penuturan (Y, Abidin., Muryati T., 2018), "Pembiasaan membaca pada anak-anak merupakan upaya gerakan literasi tentunya dengan dukungan dari berbagai elemen, maka dilakukan kegiatan membaca dalam 15 menit". Namun, dalam kegiatan pembuka relawan tidak memberi waktu hingga 15 menit untuk membaca karena keterbatasan waktu, senada dengan ungkapan salah satu relawan dan hasil observasi kedua dan ketiga kegiatan membaca di awal pembelajaran dilakukan selama lima sampai sepuluh menit saja. Berdasarkan hasil observasi pertama membaca saat kegiatan pembuka tidak dilaksanakan sedangkan observasi kedua dan ketiga kegiatan membaca di awal proses belajar mengajar dilakukan dengan sesuai apa yang sudah di susun dalam rencana pembelajaran. Senada dengan hasil wawancara bersama empat anak-anak membaca saat kegiatan pembuka tidak selalu dilakukan. Kemudian bagi anakanak pemulung yang belum dapat membaca, relawan akan membimbing anak-anak tersebut mengenal huruf dengan berbagai metode dan media yang sederhana. Seperti menggambar di atas pasir dan menggunakan lilin mainan, atau langsung menulis pada buku atau papan tulis.

\section{Kontribusi Relawan Aku Belajar Literasi saat Pelaksanaan Kegiatan Inti}

Berdasarkan rencana pembelajaran yang disusun oleh relawan Aku Belajar kegiatan inti terdiri dari kegiatan literasi yaitu memberikan motivasi kepada anak dan panduan untuk melihat, mengamati dan membaca serta menulis kembali apa yang diperolehnya. Anak pemulung yang dibina diberi bahan bacaan terkait dengan materi, critical thinking yaitu pemberian kesempatan kepada anak pemulung untuk mengumpulkan sebanyak-banyaknya perihal apa yang belum dipahami oleh anak mengenai materi yang disampaikan, collaboration yaitu pengumpulan informasi mengenai materi, communication yaitu mengemukakan pendapat, dan creativity yaitu membuat sebuah kesimpulan dari hasil pembelajaran.

Sejalan dengan pendapat (Sumprihatiningrum, 2017), "Melaksanakan kegiatan inti dalam pembelajaran maka guru sudah harus siap untuk memberikan bahan ajar yang sudah disusunnya sebelum mulai proses pembelajaran". Kegiatan literasi termasuk ke dalam proses elaborasi dimana terdapat kegiatan membaca dan menulis, critical thinking dan collaboration termasuk dalam proses eksplorasi dimana nantinya relawan Aku Belajar melibatkan anak-anak pemulung secara aktif untuk mencari informasi yang luas mengenai materi. Communication dan creativity termasuk kedalam proses konfirmasi dimana memberikan umpan balik positif dan penguatan terhadap anak pemulung yang dibina dengan mengemukakan pendapat dan memberi kesimpulan. Kemudian pengembangan dari 
budaya literasi adalah dengan adanya proses pengembangan, pembelajaran dan terakhis pembiasaan, (Saadati \& Sadli, 2019).

Berdasarkan hasil observasi pelaksanaan kegiatan inti dalam proses belajar mengajar berbasis literasi yang disesuaikan dengan rencana pembelajaran yang telah disusun yaitu, relawan Aku Belajar menyampaian materi menggunakan media power point, kegiatan membaca nyaring pada slide yang ditampilkan secara bergantian, pelaksanaan bertanya dan menjawab terkait dengan materi yang diberikan oleh relawan-relawan ini, serta belajar menulis berupa penguatan maupun mencatat materi yang telah disampaikan. Berdasarkan apa yang disampaikan oleh relawan tersebut bahwa pada kegiatan inti dalam proses pembelajaran mereka menggunakan media seperti power point, kegiatan membaca selalu dilakukan saat kegiatan inti dengan membaca nyaring materi yang ditayangkan dan materi yang ada di buku untuk memperluas pengatahuan anak pemulung dan membangun kemampuan literasi membaca anak pemulung. Sesuai komponen kemampuan membaca : Kemampuan mengakses dan mengambil informasi dari pilihan teks yang digunakan, kemampuan memahami, mengintegrasikan, dan menafsirkan bacaan, kemampuan merefleksikan, mengevaluasi, dan menghubungkan isi teks dengan pengalaman atau situasi sosial pembaca (Hendra Kurniawan, 2018).

Saat relawan meminta anak pemulung membaca dan menjelaskan makna dari bahan bacaan, anak pemulung dapat menjelaskan bacaan sesuai dengan maksud yang ingin disampaikan dari isi bacaan. Artinya kegiatan membaca yang dilakukan saat proses belajar mengajar berlangsung dapat membangun kemampuan membaca anak-anak tersebut. Pelaksanaan kegiatan menulis dilakukan relawan dengan menginstruksikan anakanak pemulung untuk merangkum, penguatan diberikan juga sesuai dengan materi yang sudah disampaikan sebelumnya. Menurut (Hendra Kurniawan, 2018), Menulis pada dasarnya merupakan sebuah proses yang diproduksi melalui berbagai tahapan: Pemerolehan ide, penulis menggunakan kepekaannya untuk mendapatkan pengetahuan dan informasi mengenai fenomena hidup, pengolahan ide, penulis dapat menggunakan kemampuan berpikir, perasaan dan imajinasi, pemroduksian ide, penulis menggunakan produk berupa bahasa.

Pemerolehan ide, pada tahap ini dilakukan relawan Aku Belajar saat kegiatan pembuka dan inti, dimana relawan melakukan rangsangan melalui fenomena pada kejadian bermasyarakat dan memintas anak-anak melihat serta mengamati lingkungan sekitar sebagai pemerolehan ide untuk kegiatan menulis sesuai dengan materi yang dibahas. Tahap kedua pengolahan ide, setelah pemerolehan ide, dilakukan pengolahan ide, anakanak binaan diminta berpikir bagaimana ide tersebut dituang dalam bentuk tulisan berbahasa. Tahap terakhir yaitu pemroduksian ide, setelah pengolahan ide, akhirnya pemroduksian, anak-anak menuangkan idenya dalam bentuk tulisan. Kegiatan menulis dilakukan untuk bahan evaluasi dan membangun pemahaman anak Pemulung yang dibina mengenai materi, serta membangun kemampuan literasi menulis mereka, sesuai yang telah disampaikan oleh (Y, Abidin., Muryati T., 2018) yaitu, pembelajaran literasi menulis bertujuan agar kegiatan menulis dapat menjadi sarana untuk memahami teks atau konsep keilmuan tertentu, keterampilan menulis dapat digunakan untuk mengkritik informasi.

\section{Kontribusi Relawan Aku Belajar Literasi saat Pelaksanaan Kegiatan Penutup}

Berdasarkan rencana pembelajaran yang telah disusun oleh relawan Aku Belajar kegiatan penutup mencakup merangkum perihal pengalaman belajar, penilaian serta menyampaikan materi pembelajaran berikutnya dan melakukan doa. Tentunya perlu ada komunikasi secara efektif yaitu dengan mengulang materi pembelajaran dan diselingi dengan permainan menjadi salah satu pilhan pada kegiatan pembelajaran, (Heppy Mariana Ritonga, 2019). Setelah peneliti melakukan observasi pada kegiatan penutup pembelajaran, peneliti menemukan bahwa relawan Aku Belajar selalu menyampaikan kesimpulan bersama anak binaan, dengan cara relawan memberikan pertanyaan kepada anak-anak informasi, pengetahuan atau pengalaman apa saja yang telah didapatkan pada pertemuan itu, setelah anak-anak menyampaikan jawaban relawan Aku Belajar menyampaikan kembali mengenai kesimpulan materi secara singkat dan melakukan konfirmasi mengenai materi yang belum dipahami oleh anak-anak binaan, hal inipun sejalan dengan hasil wawancara bersama 
empat informan, dimana kelima informan mengatakan bahwa penyampaian kesimpulan selalu dilaksanakan diakhir pembelajaran. Kesimpulan dilaksanakan agar anak-anak dapat bertanggung jawab dan mendapatkan pengalaman belajar yang telah berlangsung.

Ditemukan pula relawan yang memberikan sebuah materi untuk kegiatan pembelajaran selanjutnya, terkadang juga relawan akan bertanya mengenai materi yang sulit, maka materi tersebut akan disampaikan lagi pada pembelajaran yang akan datang. Selain itu dilakukan pula pemberian motivasi dari relawan untuk anak-anak binaan sebelum relawan mengakhiri dengan salam dan doa. Sejalan dengan pendapat (Sumantri, 2016), menyatakan "Penutup adalah kegiatan untuk mengakhiri proses pembelajaran dan merangkum hasil pembelajaran yang disampaikan serta memberikan evaluasi dan tinjauan ulang terkait materi yang disampaikan pada kegiatan literasi tersebut yang berupa tugas di rumah atau lainnya". Relawan melaksanakan kegiatan penutup sesuai dengan rencana pembelajaran yang telah disusun, kegiatan penutup yang dilakukan yaitu memberikan kesimpulan, memberikan penilaian berupa evaluasi dimana relawan Aku Belajar memberikan latihan essay dan melakukan proses membaca berbagai referensi dari buku yang ada di perpustakaan Aku Belajar serta mengamati lingkungan sekitar sebagai karya tulis, hal ini dilakukan untuk membangun kemampuan literasi membaca dan menulis anakanak, untuk penyampaian rencana pembelajaran selanjutnya berdasarkan hasil observasi dan wawancara terkadang hal ini tidak dilakukan, namun pada akhir pelaksanaan pembelajaran dilaksanakan memberikan kesimpulan agar mengetahui dan memberikan pengalaman belajar, terutama pada budaya literasi. Evaluasi yang dilaksanakan adalah berupa evaluasi setiap pertemuan dan dipelajari lagi disetiap minggunya, dengan demikian adanya budaya literasi ini nanti dapat memberikan perubahan yang terjadi pada anak-anak pemulung yang tujuannya dapat meningkatkan ketertarikan, kegemaran, dan niat baik untuk selalu membaca pada anak-anak tersebut, (Saadati \& Sadli, 2019).

\section{SIMPULAN DAN SARAN}

Kontribusi Relawan Aku belajar dalam pelaksanaan budaya literasi pada anak pemulung merupakan salah satu upaya yang dilakukan untuk memajukan pendidikan khusus bagi anak-anak yang terpinggirkan karena berbagai permasalahan yang terjadi, pada pelaksanaannya dalam proses belajar mengajar oleh Relawan AB di TPAS Batu Layang dilaksanakan kegiatan literasi dengan pembiasaan membaca buku di dalam hati selama lima menit, membaca nyaring pada power point yang ditayangkan dan buku serta kegiatan menulis yang dilakukan untuk penguatan dan kegiatan menulis sebagai penilaian yang memanfaatkan lingkungan sosial dan buku sebagai bahan untuk memperkaya ilmu pengetahuan. Secara khusus dapat disimpulkan sebagai berikut, pelaksanaan kegiatan pembuka dalam proses belajar mengajar berbasis literasi di TPAS Batu Layang didalam kegiatan pembelajarannya dilakukan dengan mengecek kehadiran anak-anak pemulung yang dibina, melakukan kegiatan apersepsi, menyampaikan tujuan, menyampaikan garis besar cakupan materi dan kegiatan literasi membaca lima menit pada buku dan bahan ajar yang diberikan. Pelaksanaan kegiatan inti dilakukan dengan menyampaikan materi, kegiatan literasi dengan membaca nyaring dan melakukan kegiatan menulis yang berupa penguatan dan mencatat mengenai materi yang telah disampaikan untuk membangun kemampuan literasi membaca dan menulis anak pemulung yang dibina. Pelaksanaan kegiatan penutup dalam proses belajar mengajar berbasis literasi dilakukan dengan menyampaikan kesimpulan materi, penugasan yang membangun literasi anak-anak pemulung yang dibina berupa karya tulis.

\section{DAFTAR PUSTAKA}

Agusta, A. S. (2020). Komunitas Baca Dalam Menyebar Virus Literasi "Perpustakaan Jalanan DIY." IQRA: Jurnal IImu Perpustakaan Dan Informasi (e-Journal), 14(1), 29. https://doi.org/10.30829/iqra.v14i1.6350

Ali Anwar, Noer Hidayah, M. A. H. (2017). Pendidikan Non Formal Dalam Meningkatkan Keterampilan Anak Jalanan. Edudeena, 1(1), 31-42. https://doi.org/10.30762/ed.v1i1.445

Aryani, F., \& Rais, M. (2018). Pemberdayaan Anak Pemulung Melalui Teknik Storytelling. 
MATAPPA: Jurnal Pengabdian Kepada Masyarakat, 1(2), 113. https://doi.org/10.31100/matappa.v1i2.208

Fitri, V. L. (2017). Pemulung Anak di TPA Muara Fajar Kecamatan Rumbai Kota Pekanbaru. JOM FISIP, 4(2), 1-12.

Handayani, T. U. (2020). Penguatan Budaya Literasi Sebagai Upaya Pembentukan Karakter. Jurnal Literasi, 4(1), 67-69.

Hardiyanti Isnin, Y. (2018). Peran Komunitas Mengajar Terhadap Pendidikan di Kecamatan Muncang Provinsi Banten (Studi Kasus: Komunitas Gerakan Ayo Mengajar). 1-140. http://repository.uinjkt.ac.id/dspace/handle/123456789/39882

Hendra Kurniawan. (2018). Literasi dalam Pembelajaran Sejarah. Yogyakarta : Gava Media. Heppy Mariana Ritonga. (2019). Komunikasi Efektif Relawan Pada Anak (Studi Deskriptif Kualitatif tentang Komunikasi Efektif Relawan dalam Proses Belajar Mengajar pada Anak-anak di Kelas Dewantara Marendal). Departemen IImu Komunikasi Fakultas IImu Sosial dan IImu Politik Universitas Sumatera Utara. https://library.usu.ac.id

Huzaemah, S. (2020). Kehidupan Sosial Ekonomi Pemulung Di Tempat Pembuangan Ahir (TPA) Kelurahan Sitimulyo Piyungan Bantul Yogyakarta. Islamic Management and Empowerment Journal, 2(1), 81-92. https://doi.org/10.18326/imej.v2i1.81-92

Imran, Aswar, K., Pratiwi, N., Aynul, N., \& Syafril, S. A. (2017). Budaya Literasi Melalui Program GLS Dalam Menumbuhkembangkan Minat Baca Siswa SD Negeri Melayu. Jurnal Penelitian Dan Penalaran, 4(2), 701-711.

Imsiyah, N. (2016). Peranan Pendidikan Nonformal Sebagai Upaya Rehabilitasi Gelandangan Dan Pengemis Di Lingkungan Pondok Sosial Kabupaten Jember. Pancaran, Vol.5,(1), 83-94.

Inayati Ma'rifah, Cut Dhien Nourwahida, A. N. A. (2018). Pola Asuh Anak dalam Keluarga Pemulung. Jurnal Harkat: Media Komunikasi Gender, 14(1), 1-11. https://doi.org/https;//doi.org/10.15408/harkat.vl4l1.10400

Ismali Nurdin, S. H. (2019). Metodologi Penelitian Sosial. Surabaya: Media Sahabat Cendekia.

Jefriyanto, C. (2019). Pemulung di era milenial (studi kasus di tpa jamur labu, aceh timur). Jurnal Investasi Islam, IV(1), 102-115.

Kuntoro, S. A. (2016). Pendidikan Nonformal (PNF) Bagi Pengembangan Sosial. Jurnal IImiah VISI PTK-PNF, 1(2), 14-18. https://core.ac.uk/download/pdf/295555318.pdf

Lelya Hilda. (2017). Kondisi Pendidikan Pekerja Anak Usia Sekolah di Tempar Pembuangan Akhir (TPA) Sampah. Jurnal Kajian Gender Dan Anak, 1(1), 12-25.

Maria Ulfa. (2019). Upaya Relawan C-Four Dalam Memotivasi Anak Penderita Kanker Di Komunitas C-Four Banda Aceh. Jurnal Bimbingan Konseling Islam, 8(5).

Muslimin. (2018). Penumbuhan Budaya Literasi Melalui Peningkatan Minat Baca Masyarakat desa. Cakrawala Pendidikan, 37(1), 107-118.

Nawawi, H. (2015). Metode Penelitian Bidang Sosial. Pontianak: Gadja Mada University Press. Pontianak: Gadja Mada University Press.

Permatasari, A. (2015). Membangun Kualitas Bangsa dengan Budaya Literasi. Seminar Nasional Bulan Bahasa UNIB (Prosiding), 146-156.

Pratiwi, E. P., \& Wibhawa, B. (2015). Pengembangan Pendidikan Non Formal Melalui Program Keaksaraan Fungsional Pusat Kegiatan Belajar Masyarakat. Prosiding Penelitian Dan Pengabdian Kepada Masyarakat, 2(2), 169-174. https://doi.org/10.24198/jppm.v2i2.13274

Putri, E. R., Aryadillah, \& Muhammad, U. (2019). Gaya Komunikasi Relawan Serambi Inspirasi Dalam Membangun Minat Belajar Anak (Studi Deskriptif Kualitatif Pada SD Dinamika Indonesia Bantar Gebang-Bekasi). Cakrawala, 19(1), 99-106. doi: https://doi.org/10.31294/jc.v19i1

Rahayu, R., \& Nurizzati. (2018). Partisipasi Relawan Terhadap Kegiatan Peningkatan Minat Baca Masyarakat di Taman Baca Suka Maju Sejahtera Kota Padang. Jurnal IImu Informasi Perpustakaan Dan Kearsipan, 7(1), 246-258. http//.ejurnal.unp.ac.id

Rahmadhani, A., \& Raksun, A. (2021). Pelatihan Batu (Baca Dan Tulis) Untuk Meningkatkan Budaya Literasi Di Pkbm Oi Rida Desa Nata Kecamatan Palibelo Kabupaten Bima. Jurnal Pengabdian Magister Pendidikan IPA, 3(2). 
https://doi.org/10.29303/jpmpi.v3i2.572

Rohim, D. C., \& Rahmawati, S. (2020). Peran Literasi dalam Meningkatkan Minat Baca Siswa di Sekolah Dasar. Jurnal Review Pendidikan Dasar: Jurnal Kajian Pendidikan Dan Hasil Penelitian,

https://journal.unesa.ac.id/index.php/PD/article/view/10412/4379

Rusdiana, Sulistyarini, I. R. (2021). Analisis Proses Belajar Mengajar Bebasis Literasi Pada Mata Pelajaran Sosiologi di Madrasah Aliyah Islamiyah Pontianak. Jurnal Pendidikan Dan Pembelajaran Khatulistiwa, 10(1), 1-9.

Saadati, B. A., \& Sadli, M. (2019). Analisis Pengembangan Budaya Literasi Dalam Meningkatkan Minat Membaca Siswa Di Sekolah Dasar. TERAMPIL: Jurnal Pendidikan Dan Pembelajaran Dasar, 6(2), 151-164. https://doi.org/10.24042/terampil.v6i2.4829

Sholihin et al. (2019). Indeks Aktivitas Literasi Membaca 34 Provinsi. Pusat Penelitian Kebijakan Pendidikan Dan Kebudayaan, Badan Penelitian Dan Pengembangan, Kementrian Pendidikan Dan Kebudayaan.

Sudiro, L. (2012). Pemulung Anak-Anak Yang Masih Sekolah ( Studi: Fungsi Keluarga Pada Keluarga Pemulung Anak-anak Di Tempat Pembuangan Akhir Sampah Ganet Tanjungpinang ). In Naskah Publikasi. Univesitas Maritim Raja Ali Haji Tanjung Pinang.

Sugiyono. (2015). Metode Penelitian Kombinasi (Mix Methods). Alfabeta.

Sumantri, M. S. (2016). Strategi Pembelajaran. Yogyakarta: Ar-Ruzz Media.

Sumprihatiningrum, J. (2017). Strategi Pembelajaran (teori dan aplikasi). Yogyakarta: Arruzz Media.

Suyanto, B. (2013). Masalah Sosial Anak Edisi Revisi. Jakarta: Prenada media Group.

Ulmi, T. F., \& Ramadhan, I. (2021). Analisis Peran Relawan Organisasi Aku Belajar Dalam Meningkatkan Minat Belajar Anak Pemulung di TPAS Batu Layang. Jurnal Pendidikan Dan Pembelajaran Khatulistiwa, 10(3), 1-11.

Wang, Q., \& Anderson, R. (2010). An Early Reading Intervention for an At-Risk Chinese First Grader. Literacy Teaching and Learning, 15, 81-108.

Y, Abidin., Muryati T., Y. H. (2018). Pembelajaran Literasi: Strategi Meningkatkan Kemampuan Literasi, Matematika, Sains, Membaca, dan Menulis. Jakarta: Bumi Aksara. 